\title{
Klinische kennis kan niet alleen in de praktijk verkregen worden ${ }^{1}$
}

\author{
P.F. de Vries Robbé
}

Bij het werk in de kliniek wordt veel ervaringskennis verworven, maar is die kennis voldoende voor ons praktische werk? Scherpbier geeft aan dat de arts het probleem van de patiënt moet kunnen analyseren, maar dat deze tevens graag ziet dat de arts kennis opzoekt. ${ }^{1}$

Deze twee vaardigheden vragen om kennis over hoe wij problemen moeten analyseren en hoe wij relevante inhoudelijke kennis moeten opzoeken, waarbij het dus gaat om methodologische kennis. Deze kennis werd in het verleden in de kliniek geleerd 'door het afkijken van de kunst', een ambachtelijke benadering. Met de snel toenemende hoeveelheid wetenschappelijke kennis en ervaringskennis en de veranderende gezondheidszorg zijn ooit besproken voorbeelden en onze eigen ervaringskennis niet meer toereikend. Methodologische kennis is dan van essentieel belang.

Goede docenten zijn in staat stappen die ze maken, in het kader van een onderwijssituatie, expliciet te benoemen. Dit gebeurt dan steeds aan de hand van het voorliggende concrete geval, waardoor het handelen in de betreffende casus inzichtelijk wordt gemaakt. ${ }^{2}$ Er wordt echter slechts weinig aandacht besteed aan de casus- en specialismeoverstijgende aanpak van het handelen. ${ }^{3}$ Bovendien kunnen verschillende docenten tegenstrijdige boodschappen verkondigen, zoals bij de vraag of de voorgeschiedenis nu in het begin van de anamnese of aan het einde moet komen. En wie kan een student casus-onafhankelijk uitleggen aan welke criteria een goede differentiële diagnose moet voldoen? Moeten alle

P.F. de Vries Robbé $(\square)$

Prof. dr. P.F. de Vries Robbé is arts-informaticus.

Correspondentieadres:Prof. dr. P.F. de Vries Robbé,

Universitair Medisch Centrum St Radboud, afd. Medische

Informatiekunde, Huispost 152MI, Postbus 9101, $6500 \mathrm{HB}$

Nijmegen,p.devriesrobbe@mi.umcn.nl. opties elkaar uitsluiten, moeten ze elk alle symptomen verklaren? Uit eerder onderzoek is gebleken dat ook veel 'metatermen', zoals 'pathogenese', 'etiologie', 'complicatie' en 'differentiaaldiagnose', in de geneeskunde door verschillende docenten verschillend worden gehanteerd. ${ }^{4}$ Hoewel het hier onderzoek betreft van enkele decennia geleden, heb ik geen aanwijzingen dat de situatie inmiddels verbeterd is.

Met expliciet onderwijs in de methodologische aspecten van het klinisch redeneren wordt beoogd (a) de student een consistent beeld te geven van de methodologische aspecten van het medisch handelen; (b) de student te leren hoe het handelen helder (eventueel achteraf) beargumenteerd kan worden voor een goede verantwoording ten opzichte van de patiënt en voor een betekenisvolle overdracht; (c) de student op het juiste moment op een effectieve wijze literatuur te laten opzoeken; en (d) de docent helder en consistent onderwijs te laten geven en op een goede wijze te laten superviseren in de kliniek. Daarnaast moet expliciet specialisme-overstijgende aandacht worden besteed aan de statusvoering; dan kan ook de verslaglegging van de argumentatie aan de orde komen.

Medici dienen expliciet methodologische scholing te krijgen, net zoals zij hun basisvakken leren. Dat kan natuurlijk in de kliniek, maar als studenten reeds in de preklinische fase oefeningen krijgen in het klinisch redeneren, dient ook in die fase de daarvoor noodzakelijke methodologische kennis te worden gedoceerd.

Belangenconflict: geen gemeld.

Financiële ondersteuning: geen gemeld.

\section{Summary}

\footnotetext{
${ }^{1}$ Dit artikel verschijnt ook in het Nederlands Tijdschrift voor Geneeskunde. 135 Pro en contra in medisch onderwijs
} 
Methodological training is necessary in order to cope with the ever-growing volume of knowledge by clinical experience. This training involves ways of reasoning and collecting relevant evidence. This type of instruction should be given in concurrence with the first exercises in clinical reasoning. Such instruction should focus on acquisition of the ability to clearly substantiate decisions made during medical practice. (De Vries Robbé PF. Clinical knowledge cannot only be acquired in practice. Dutch Journal of Medical Education 2007;26(3):135136.)

\section{Literatuur}

Scherpbier AJJA. In de spreekkamer is opzoekkennis belangrijker dan parate kennis. Ned Tijdschr Geneeskd 2006;150:453.

Stuyt PMJ, Vries Robbé PF de, Meer JWM van der. Kleinschalig theoretisch klinisch lijnonderwijs.Ned Tijdschr Geneeskd 1994;138:1729.
Custers EJ, Stuyt PMJ, Vries Robbé PF de. Clinical problem analysis (CPA): a systematic approach to teaching complex medical problem solving. Acad Med 2000;75:291-7.

Bender W, Hoedemaeker PJ, Vries Robbé PF de. Eenduidigheid van begrippen. Med Contact 1979;37:1182-4. 